
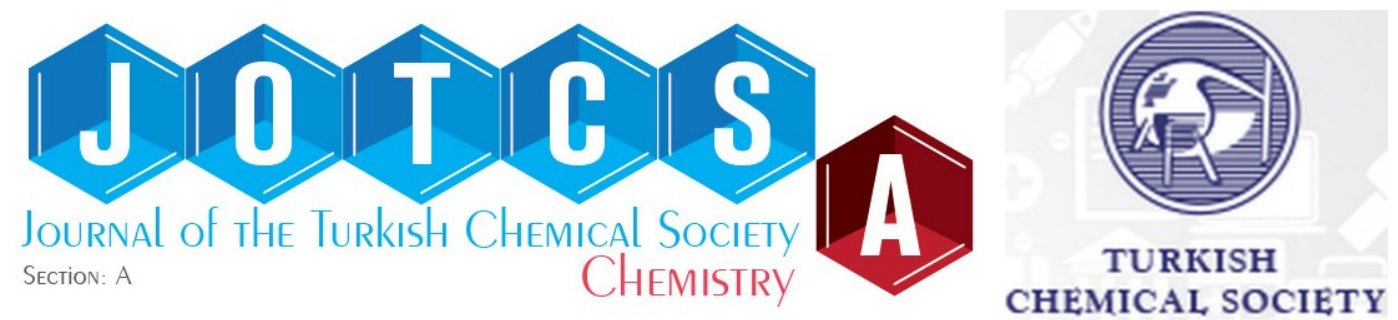

\title{
A Turn-on Fluorescent Sensor For Cadmium Ion Detection In Aqueous Solutions
}

\author{
Ziya Aydin $* \square$ \\ *Vocational School of Technical Sciences, Karamanoglu Mehmetbey University, 70200 Karaman, Turkey.
}

Abstract: Fluorescent sensors have attracted an important interest due to their advantages such as high selectivity, rapid response, easy use, etc. In this study, a rhodamine based fluorescent sensor, RhDP, was synthesized, and used for selective detection of $\mathrm{Cd}^{2+}$ ions. The sensor responds to $\mathrm{Cd}^{2+}$ via the coordination induced fluorescence activation (CIFA) mechanism. RhDP gives a very fast and reversible fluorescence response to $\mathrm{Cd}^{2+}$ in the presence of the metal ions tested. The complex stoichiometry between RhDP and $\mathrm{Cd}^{2+}$ was found to be $1: 1$ and the binding constant was calculated as $2.70 \times 10^{7} \mathrm{M}^{-1}$ in acetonitrile $(A C N) / H E P E S$ buffer $(10 \mathrm{mM}, \mathrm{pH}: 7.05, \mathrm{v} / \mathrm{v} 1: 1)$. The fluorescent detection limit of RhDP for $\mathrm{Cd}^{2+}$ was found to be $0.218 \mu \mathrm{M}$, which gave a marked sensitivity towards $\mathrm{Cd}^{2+}$.

Keywords: Fluorescence, Sensor, Cadmium, Rhodamine B, Turn-on.

Submitted: October 28, 2019. Accepted: December 27, 2019.

Cite this: Aydın Z. A Turn-on Fluorescent Sensor For Cadmium Ion Detection In Aqueous Solutions. JOTCSA. 2020;7(1):277-86.

DOI: https://doi.org/10.18596/jotcsa.638912.

*Corresponding author. ziyaaydin@kmu.edu.tr; ziyaaydin@yahoo.com.

\section{INTRODUCTION}

Cadmium, which is one of the highly toxic heavy metals, is widely distributed in soil, water and crops, generated from volcanic eruption, the combustion of fossil fuels, $\mathrm{Ni}-\mathrm{Cd}$ rechargeable batteries, fertilizers, paint pigments, etc., causing serious problems for human health (1-3). Cadmium ion $\left(\mathrm{Cd}^{2+}\right)$ shows high affinity to sulfur, and it can interfere with metal ions such as $\mathrm{Ca}^{2+}$ and $\mathrm{Zn}^{2+}$ to replace in the binding sites of some enzymes $(4,5)$. It causes dysfunction of these enzymes, causing serious damage to the organs. Cadmium and cadmium compounds are category I carcinogens (6), and are known to be associated with cancer mortality, hepatic and renal damage, and cardiovascular disease (7-9). Thus, it is an essential point to develop detection methods for cadmium.

Several methods have been reported to detect $\mathrm{Cd}^{2+}$; however, these methods are generally expensive and have complicated sample pretreatment procedures and sophisticated synthetic procedure (10-13). As an alternative method, fluorescence spectroscopy requires easier procedures. In recent years, considerable effort has been dedicated towards the design and preparation of various colorimetric and fluorescent sensors for the detection of $\mathrm{Cd}^{2+}$ ions; however, they respond to $\mathrm{Cd}^{2+}$ by fluorescence quenching (14-16). Some organic molecules can also be used as turn-on fluorescent sensor for $\mathrm{Cd}^{2+}$ (17-19); however, many of them have some technical drawbacks. For example, some $\mathrm{Cd}^{2+}$-selective sensors also give response to $\mathrm{Zn}^{2+}$ ions because they are in the same group of the periodic table and have similar properties $(20,21)$. Some $\mathrm{Cd}^{2+}$ sensors have a poor detection limit (22) and complicated synthetic routes $(23,24)$. Thus, better turn-on fluorescent sensors should be developed for $\mathrm{Cd}^{2+}$ ions. Rhodamine-based sensors are believed to be the ideal platforms for turn-on fluorescent tools because of its excellent 
photophysical properties (25). Since the report of Czarnik's $\mathrm{Cu}^{2+}$-sensor (26), various rhodaminebased turn-on fluorescent sensors have been reported for $\mathrm{Hg}^{2+}(27), \mathrm{Fe}^{3+}(28), \mathrm{Cr}^{3+}$ (29), $\mathrm{Cu}^{2+}$ (30), and $\mathrm{Pd}^{2+}$ (31). So far, a few rhodaminebased turn-on fluorescent sensors have been reported for $\mathrm{Cd}^{2+}(32-36)$. However, some of these sensors also have some technical drawbacks such as interference with other metal ions (36) and sensing to hydrogen ions (33). In this paper, a simple and reliable turn-on rhodamine based fluorescent sensor RhDP for $\mathrm{Cd}^{2+}$ has been introduced. The sensor exhibited good selectivity and sensitivity for $\mathrm{Cd}^{2+}$. The sensor gives response to $\mathrm{Cd}^{2+}$ very fast ( $<1$ minute) and is stable even under $\mathrm{pH} 5$.

\section{EXPERIMENTAL}

\section{Materials and general methods}

Rhodamine $B$ base, 2,6-diacetylpyridine and dimethyl aspartate were purchased from TCI America. The solvents and the other chemicals used in the experiments were obtained commercially. The solution of $\mathrm{Fe}^{2+}$ and $\mathrm{Fe}^{3+}$ were prepared by dissolving in $0.1 \mathrm{M} \mathrm{HCl}$. Unless otherwise stated, the stock solutions of the metal ions tested were prepared from chloride salts or nitrate salts of them in deionized water. A stock solution of RhDP $(500 \mu \mathrm{M})$ was prepared in ACN and diluted to $20 \mu \mathrm{M}$ with ACN/HEPES buffer (10 $\mathrm{mM}, \mathrm{pH}: 7.05, \mathrm{v} / \mathrm{v} 1: 1$ ).

An NMR spectrometer (Bruker DRX-300) was used to record ${ }^{1} \mathrm{H}$ and ${ }^{13} \mathrm{C}$ NMR spectra. A Perkin Elmer API 150EX mass spectrometer was used to perform ESI-MS analyses. A Perkin Elmer Lambda 25 spectrophotometer at $293 \mathrm{~K}$ was used to record UV-Vis spectra. Fluorescent intensities were collected with a Perkin-Elmer LS55 luminescence spectrometer at $293 \mathrm{~K}$.

\section{Synthesis of RhDP}

Rhodamine B hydrazine was synthesized using the published method (37). Before RhDP was synthesized, the intermediate product (1) was prepared and the synthesis of 1 was explained below.

Synthesis of 1 : Rhodamine B hydrazine (1 mmol, $0.556 \mathrm{~g}$ ) and 2,6-diacetylpyridine (1 mmol, 0.162 g) were dissolved and mixed in boiling ethanol. The mixture was then refluxed for 5 hours. The solution was then cooled and allowed to stand at room temperature. After the solvent was evaporated under reduced pressure, the crude product was obtained. The crude product was then purified by silica gel column chromatography using $\mathrm{CH}_{3} \mathrm{OH} / \mathrm{CH}_{2} \mathrm{Cl}_{2}(1: 20, \mathrm{v} / \mathrm{v})$ as eluent to obtain 0.405 $\mathrm{g}$ of 1 (yield, $56 \%) .{ }^{1} \mathrm{H}$ NMR $\left(\mathrm{CDCl}_{3}, 300 \mathrm{MHz}\right.$ $\delta(p p m): 8.72(\mathrm{~d}, 1 \mathrm{H}), 8.08(\mathrm{~d}, 1 \mathrm{H}), 7.78-7.67$ $(\mathrm{m}, 2 \mathrm{H}), 7.62-7.53(\mathrm{~m}, 2 \mathrm{H}), 7.23(\mathrm{~d}, 1 \mathrm{H}), 6.54-$ $6.46(\mathrm{~m}, 4 \mathrm{H}), 6.21(\mathrm{~d}, 2 \mathrm{H}), 3.63(\mathrm{~m}, 8 \mathrm{H}), 2.70$ $(\mathrm{s}, 3 \mathrm{H}), 1.91(\mathrm{~s}, 3 \mathrm{H}), 1.21(\mathrm{t}, 12 \mathrm{H}) ;{ }^{13} \mathrm{C} N M R$ $\left(\mathrm{CDCl}_{3}, 75 \mathrm{MHz} \delta(\mathrm{ppm}): 168.8,154.3,153.3\right.$, $152.6,150.1,148.3,147.8,145.7,137.7,133.8$, $129.6,128.1,127.4,124.5,123.2,119.9,118.9$, 108.1, 107.097.7, 66.5, 51.7, 44.3, 21.7, 12.7; ESI-MS: found: $m / z=602.1[\mathrm{M}+\mathrm{H}]^{+}$, calcd for $\mathrm{C}_{37} \mathrm{H}_{39} \mathrm{~N}_{5} \mathrm{O}_{3}=601.2$.

Synthesis of RhDP : 1 (0.670 mmol, $0.405 \mathrm{~g})$ and dimethyl aspartate $(0.670 \mathrm{mmol}, 0,076 \mathrm{~g})$ were dissolved in ethanol $(15 \mathrm{~mL})$. The mixture was then refluxed overnight. The solvent was evaporated under vacuum and the crude product was purified by alumina gel column using $\mathrm{CH}_{2} \mathrm{Cl}_{2}$ to $\mathrm{CH}_{2} \mathrm{Cl}_{2} / \mathrm{MeOH}$ as eluent to afford RhDP as a yellow solid (0.115 g, yield, 23\%). ${ }^{1} \mathrm{H}$ NMR $\left(\mathrm{CDCl}_{3}, 300\right.$ $\mathrm{MHz} \delta(\mathrm{ppm}): 8.82(\mathrm{~d}, 1 \mathrm{H}), 8.14(\mathrm{~d}, 1 \mathrm{H}), 7.78-$ $7.67(\mathrm{~m}, 2 \mathrm{H}), 7.62-7.53(\mathrm{~m}, 2 \mathrm{H}), 7.23(\mathrm{~d}, 1 \mathrm{H})$, 6.54-6.46 (m, 4H), 6.21 (d, $2 \mathrm{H}), 3.82(\mathrm{~s}, 6 \mathrm{H})$ $3.63(\mathrm{~m}, 8 \mathrm{H}), 3.01(\mathrm{~m}, 1 \mathrm{H}), 2.70(\mathrm{~s}, 3 \mathrm{H}), 2.58(\mathrm{~d}$, $2 \mathrm{H}) 1.91(\mathrm{~s}, 3 \mathrm{H}), 1.21(\mathrm{t}, 12 \mathrm{H}) ;{ }^{13} \mathrm{C} \mathrm{NMR}\left(\mathrm{CDCl}_{3}\right.$, $75 \mathrm{MHz} \delta(\mathrm{ppm}): 158.8,154.3,153.3,152.6$, $150.1,148.3,147.8,145.7,137.7,133.8,129.6$, $128.1,127.4,124.5,123.2,119.9,118.9,108.1$, 107.097.7, 66.5, 54.6, 51.7, 44.3, 41.6, 36.1, 21.7, 12.7; ESI-MS: found: $m / z=745.2[\mathrm{M}+\mathrm{H}]^{+}$, calcd for $\mathrm{C}_{43} \mathrm{H}_{48} \mathrm{~N}_{6} \mathrm{O}_{8}=744.3$.

\section{Binding studies}

The binding constant between RhDP and $\mathrm{Cd}^{2+}$ was determined with the absorption values at $557 \mathrm{~nm}$ using the method explained below.

$S+M \Leftrightarrow S M$

Where $\mathrm{S}=$ sensor, $\mathrm{M}=\mathrm{Cd}^{2+}$ and $\mathrm{SM}=\mathrm{RhDP}+\mathrm{Cd}^{2+}$

The complex apparent binding constant is given by $K=\frac{[S M]}{[S][M]}$

Here, the concentrations at equilibrium.

$$
F_{C}=\frac{(A u-A m)}{(A u-A c)}=K=\frac{[S M]}{[S]}
$$

$\mathrm{Fc}$ is the fraction of $\mathrm{S}$ that formed a complex, [SM] is concentration at equilibrium, [S] is initial concentration. Au; Am; and Ac are the absorbance (at a chosen wavelength) of solutions of $\mathrm{S}$ only (before $\mathrm{Cd}^{2+}$ was added); $\mathrm{S}$ and SM mixture (somewhere in the middle of titration); and SM only (at the end of titration) respectively. The concentration of free $\mathrm{Cd}^{2+}$ at equilibrium, $[\mathrm{M}]_{\mathrm{e}}$, is found with the following identity.

$$
\begin{aligned}
& {[M]_{e}=[M]_{0}-[S M]_{e}=[M]_{0}-F_{c}[S]_{0}} \\
& K=\frac{F_{c}}{1-F_{c}} \times \frac{1}{[M]_{e q}}
\end{aligned}
$$

\section{Quantum yield}

Quantum yields of RhDP and RhDP $+\mathrm{Cd}^{2+}$ were calculated using the method reported (38). 


$$
\phi=\phi R\left(\frac{G r a d}{\operatorname{Grad}_{R}}\right)\left(\frac{\eta^{2}}{\eta_{r}^{2}}\right)
$$

$\Phi \mathrm{RhDP}=0.0187, \Phi \mathrm{RhDP}+\mathrm{Cd}^{2+}=0.219$

\section{RESULTS and DISCUSSION}

The strategy for the development of RhDP is as follows: 1) Rhodamine $B$ was chosen as a fluorophore due to its excellent photophysical properties (39). 2) Rhodamine B was reacted with hydrazine to lower the sensitivity of the rhodamine part to $\mathrm{pH}$ and be suitable for the next step. 3) Rhodamine $B$ hydrazine was first reacted with 2,6diacetyl pyridine and then reacted with dimethyl aspartate to obtain the binding part for $\mathrm{Cd}^{2+}$. The binding part consists of three nitrogen and three oxygen atoms to afford one six-membered ring and four five-membered rings. The sensor, RhDP, was synthesized in a three step procedure (the synthesis of RhDP was explained in the experimental part) with overall yield of $23 \%$ (Scheme 1). The sensor was characterized by NMR $\left({ }^{13} \mathrm{C}\right.$ NMR and ${ }^{1} \mathrm{H}$ NMR) and mass spectrometry.

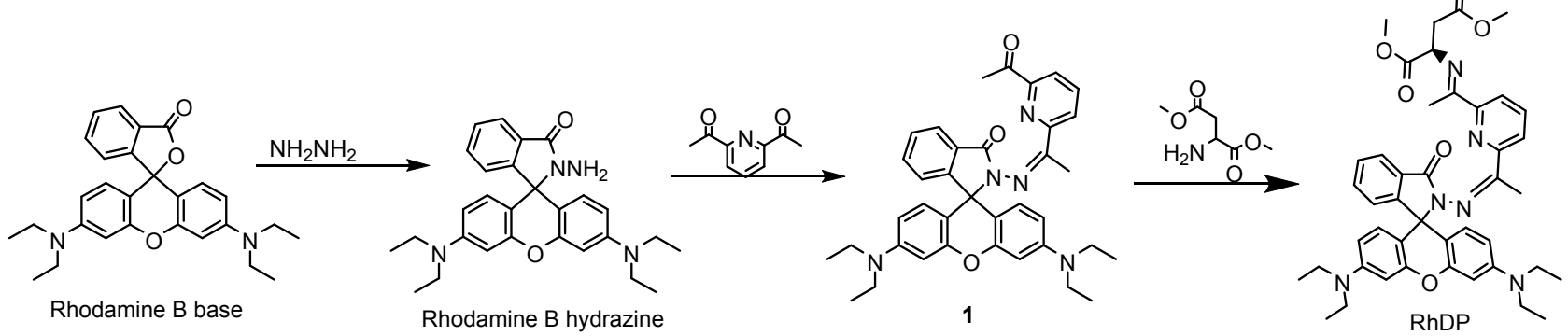

Scheme 1: Synthesis of RhDP.

The absorption spectral changes of RhDP after coordination with $\mathrm{Cd}^{2+}$ in ACN/HEPES buffer (10 $\mathrm{mM}, \mathrm{pH}: 7.05, \mathrm{v} / \mathrm{v} 1: 1)$ were investigated at first. The absorption spectra were recorded at approximately 5 minutes after the addition of each $\mathrm{Cd}^{2+}$ concentration. RhDP is a colorless compound showing very weak absorption $\left(\varepsilon=7.6 \times 10^{3} \mathrm{M}^{-1}\right.$ $\mathrm{cm}^{-1}$ ) in the $450-650 \mathrm{~nm}$ region; indicating that RhDP was dominantly in the formation of the spirocylic form (40). Upon addition of $\mathrm{Cd}^{2+}$ to the colorless solution of RhDP, it instantaneously turned to pink (see inset in Figure 1a) with an absorption band appearing at $557 \mathrm{~nm}(\varepsilon=3.15 \times$

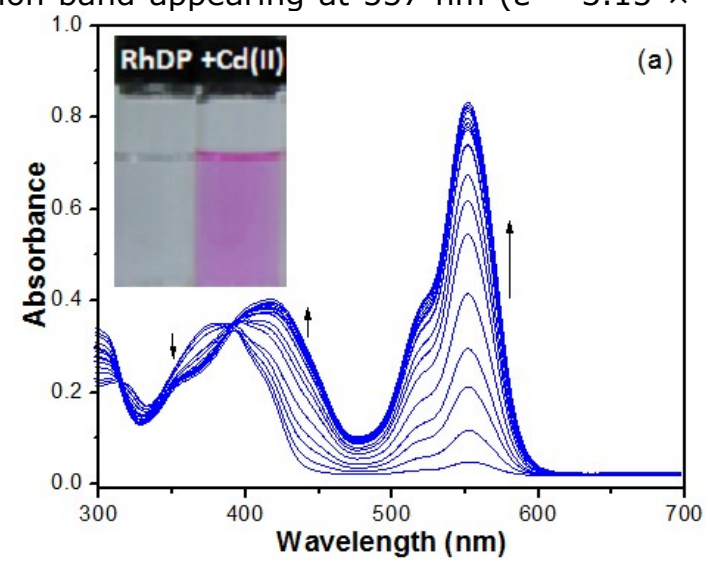

$10^{5} \mathrm{M}^{-1} \mathrm{~cm}^{-1}$ ) and growing in intensity with the gradual addition of $\mathrm{Cd}^{2+}$ (Figure $\left.1 \mathrm{a}\right)$, which implies that the rhodamine spirocylic ring was under ringopening process (41) as a result of $\mathrm{Cd}^{2+}$ binding. In order to examine the selectivity of RhDP to $\mathrm{Cd}^{2+}$, the absorption spectra of RhDP with various metal ions $\mathrm{Cr}^{3+}, \mathrm{Cu}^{2+}, \mathrm{Na}^{+}, \mathrm{Hg}^{2+}, \mathrm{Mg}^{2+}, \mathrm{Ca}^{2+}, \mathrm{Fe}^{3+}$, $\mathrm{Zn}^{2+}, \mathrm{Ag}^{+}, \mathrm{Pb}^{2+}, \mathrm{K}^{+}, \mathrm{Co}^{2+}, \mathrm{Fe}^{2+}, \mathrm{Mn}^{2+}$ and $\mathrm{Ni}^{2+}$ were collected. As shown in Figure 1b, only $\mathrm{Cd}^{2+}$ gave a large response to RhDP while other metal ions showed little change in maximum UV-Vis absorption peak (only $\mathrm{Cu}^{2+}$ and $\mathrm{Co}^{2+}$ give response to the sensor).

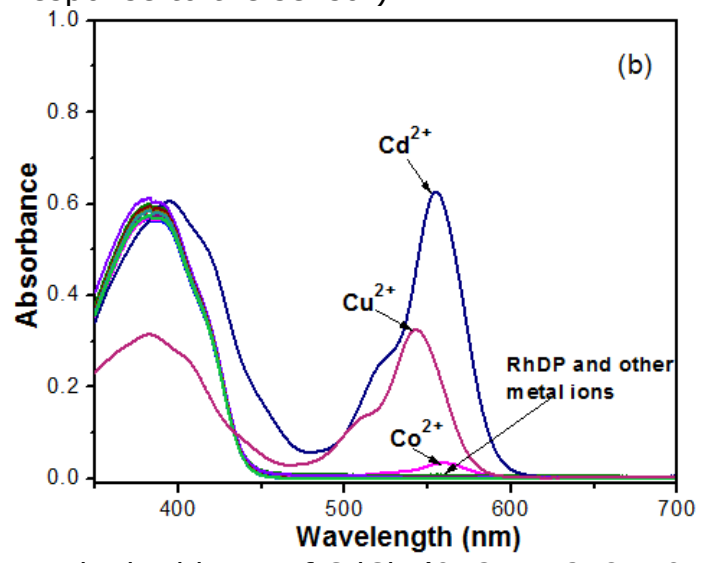

Figure 1: (a) Absorption spectra of $20 \mu \mathrm{M}$ RhDP with gradual addition of $\mathrm{CdCl}_{2}(0,2,4,6,8,10,12,14$,

$16,18,20,25,30,35,40 \mu \mathrm{M}$ respectively) in ACN/HEPES buffer $(10 \mathrm{mM}, \mathrm{pH}: 7.05, \mathrm{v} / \mathrm{v} 1: 1) ;(\mathrm{b})$ Absorption spectra of RhDP $(20 \mu \mathrm{M})$ with various metal ions $\left(20 \mu \mathrm{M}\right.$ for $\mathrm{Cd}^{2+}, \mathrm{Cu}^{2+}, \mathrm{Ni}^{2+}, \mathrm{Mn}^{2+}, \mathrm{Hg}^{2+}, \mathrm{Zn}^{2+}$, $\mathrm{Ag}^{+}, \mathrm{Pb}^{2+}, \mathrm{Fe}^{3+}, \mathrm{Co}^{2+}, \mathrm{Fe}^{2+}, \mathrm{Cu}^{+}$and $\mathrm{Cr}^{3+} ; 100 \mu \mathrm{M}$ for $\mathrm{Ca}^{2+}, \mathrm{Mg}^{2+}, \mathrm{K}^{+}$and $\mathrm{Na}^{+}$)

Before performing fluorescent experiments for RhDP, the time evolution of RhDP, the response of the RhDP to 1 equivalent of $\mathrm{Cd}^{2+}$ and their stability in ACN/HEPES buffer (10 mM, pH: 7.05, v/v 1:1) were studied. As seen in Figure 2, the interaction of RhDP with $\mathrm{Cd}^{2+}$ was completed in less than 5 minutes, and it was stable for 15 hours. RhDP itself was stable in aqueous solution for $8 \mathrm{~h}$ (emission at 
$591 \mathrm{~nm}$ ). The results showed that the coordination of $\mathrm{Cd}^{2+}$ to RhDP also increased the stability of the sensor.

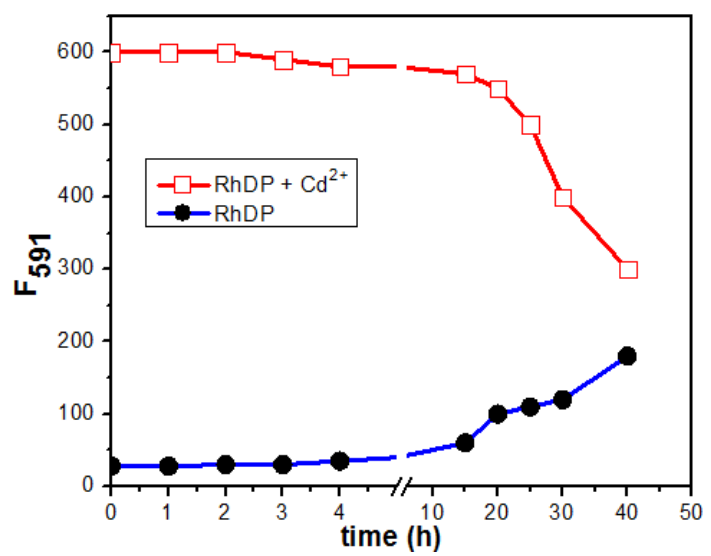

Figure 2: Time evolution for $\operatorname{RhDP}(20 \mu \mathrm{M})$ and $\operatorname{RhDP}+\mathrm{Cd}^{2+}(20 \mu \mathrm{M})$.

To examine the fluorescent response to $\mathrm{Cd}^{2+}$, a solution of RhDP in ACN/HEPES buffer (10 mM, $\mathrm{pH}$ : 7.05, v/v 1:1) was titrated with various concentrations of $\mathrm{Cd}^{2+}$ and monitored with a fluorometer by excitation at $530 \mathrm{~nm}$. The sensor $(\Phi=0.0187)$ showed a very weak fluorescent emission at $580 \mathrm{~nm}$. Upon the addition of $\mathrm{Cd}^{2+}$ to the RhDP solution, a large increase in fluorescence was observed at 591 $\mathrm{nm}$, which is attributed to the ring opening induced by the complexation of $\mathrm{Cd}^{2+}$ (Figure $3 a)$. The changes in the fluorescent properties of RhDP as a result of addition of the various metal ions were tested at $591 \mathrm{~nm}$ (excitation at $530 \mathrm{~nm}$ ). As seen in Figure $3 b$ and blue bars in Figure $4 b$, only $\mathrm{Cd}^{2+}$ gave a great response to RhDP while other metal ions showed little change in maximum fluorescent intensity peak (similar as that observed by UV-Vis, only $\mathrm{Cu}^{2+}$ and $\mathrm{Co}^{2+}$ showed a minor enhancement in fluorescence under these conditions.). The emission intensity enhancement at $591 \mathrm{~nm}(\Phi=0.219)$ is greater than 40-fold with 1.0 equivalent of $\mathrm{Cd}^{2+}$, which was redshifted about $11 \mathrm{~nm}$ compared with that of RhDP, suggesting that RhDP is a great turn-on fluorescent sensor for $\mathrm{Cd}^{2+}$.
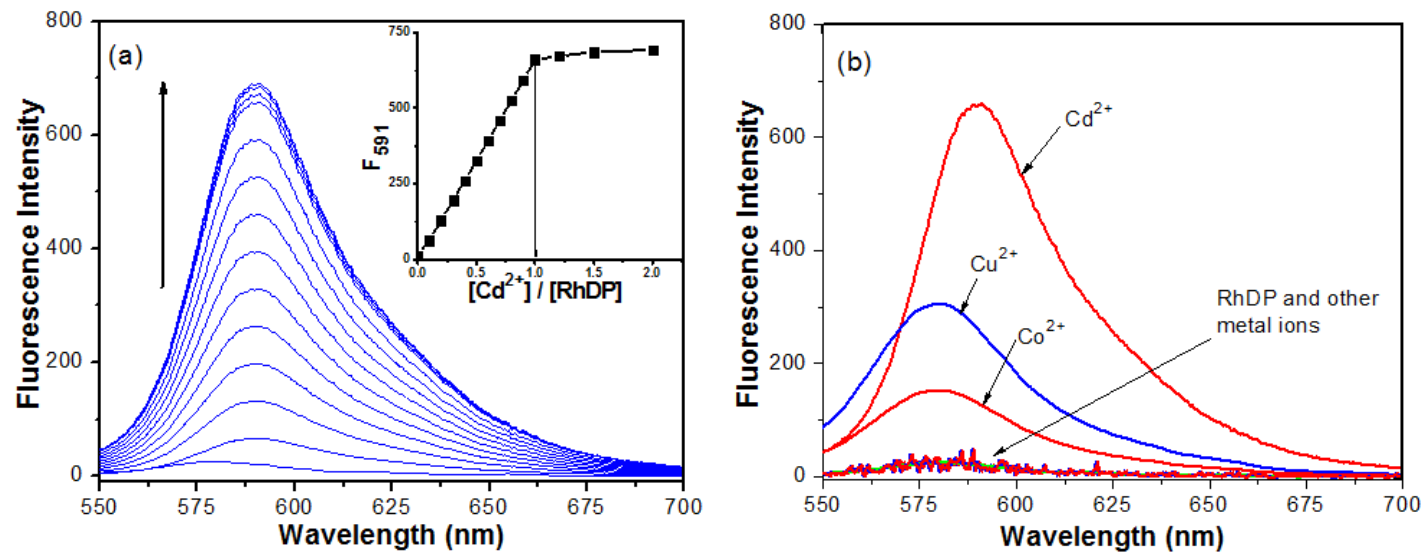

Figure 3: (a) Fluorescence intensities of $20 \mu \mathrm{M}$ RhDP with gradual addition of $\mathrm{CdCl}_{2}(0,2,4,6,8,10,12$, $14,16,18,20,25,30,40 \mu \mathrm{M}$ respectively) in ACN/HEPES buffer $(10 \mathrm{mM}, \mathrm{pH}: 7.05, \mathrm{v} / \mathrm{v} 1: 1) ;(\mathrm{b})$

Fluorescence spectra of RhDP $(20 \mu \mathrm{M})$ with various metal ions $\left(20 \mu \mathrm{M}\right.$ for $\mathrm{Cd}^{2+}, \mathrm{Cu}^{2+}, \mathrm{Ni}^{2+}, \mathrm{Mn}^{2+}, \mathrm{Hg}^{2+}$ $\mathrm{Zn}^{2+}, \mathrm{Ag}^{+}, \mathrm{Pb}^{2+}, \mathrm{Fe}^{3+}, \mathrm{Co}^{2+}, \mathrm{Cu}^{+}, \mathrm{Fe}^{2+}$ and $\mathrm{Cr}^{3+} ; 100 \mu \mathrm{M}$ for $\mathrm{Ca}^{2+}, \mathrm{Mg}^{2+}, \mathrm{Na}^{+}$and $\mathrm{K}^{+}$).

Rhodamine-based sensors also give response to hydrogen ions $(37,41)$. To clarify whether the sensor is in the closed-form in ACN/HEPES buffer (10 $\mathrm{mM}, \mathrm{pH}: 7.05, \mathrm{v} / \mathrm{v} 1: 1)$, the stability of the sensor at different $\mathrm{pH}$ values was investigated and monitored by absorption spectra. The $\mathrm{pH}$ of the solutions was adjusted by adding $\mathrm{HCl}(0.1 \mathrm{M})$ into the solutions. The absorption of RhDP at different $\mathrm{pH}$ values was plotted in Figure $4 \mathrm{a}$. The sensor is stable even under $\mathrm{pH}$ 5.5.
The detection of the target cation in the presence of other metal ions in real sample is an important assay. Competitive experiments were performed to confirm the high selectivity of the detection system. First, the meal ions such as $\mathrm{Cr}^{3+}, \mathrm{Cu}^{2+}$, $\mathrm{Na}^{+}, \mathrm{Hg}^{2+}, \mathrm{Mg}^{2+}, \mathrm{Ca}^{2+}, \mathrm{Fe}^{3+}, \mathrm{Zn}^{2+}, \mathrm{Ag}^{+}, \mathrm{Pb}^{2+}, \mathrm{K}^{+}$, $\mathrm{Co}^{2+}, \mathrm{Fe}^{2+}, \mathrm{Mn}^{2+}$ and $\mathrm{Ni}^{2+}$ were pre-incubated with RhDP. As expected, no remarkable change was observed (blue bars in Figure 4b). However, the 
addition of 1 equivalent of $\mathrm{Cd}^{2+}$ to each of them caused fluorescence enhancement (red bars in Figure 4b). These results showed that none of the

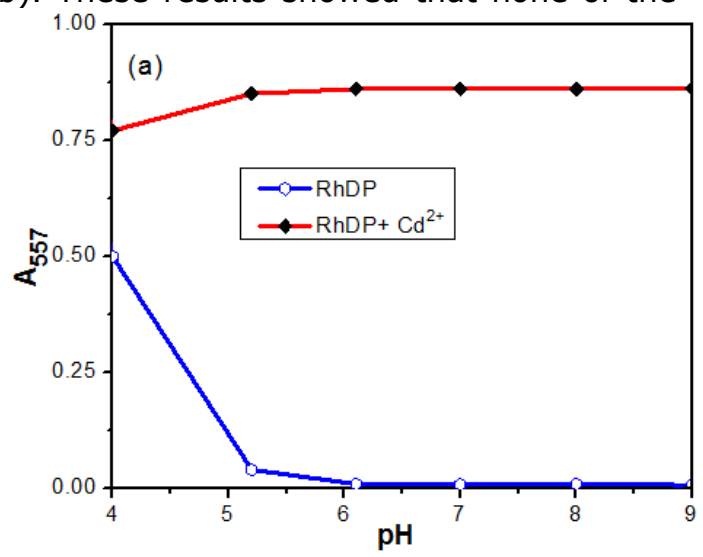

metal ions tested affected the sensing properties of RhDP to $\mathrm{Cd}^{2+}$.

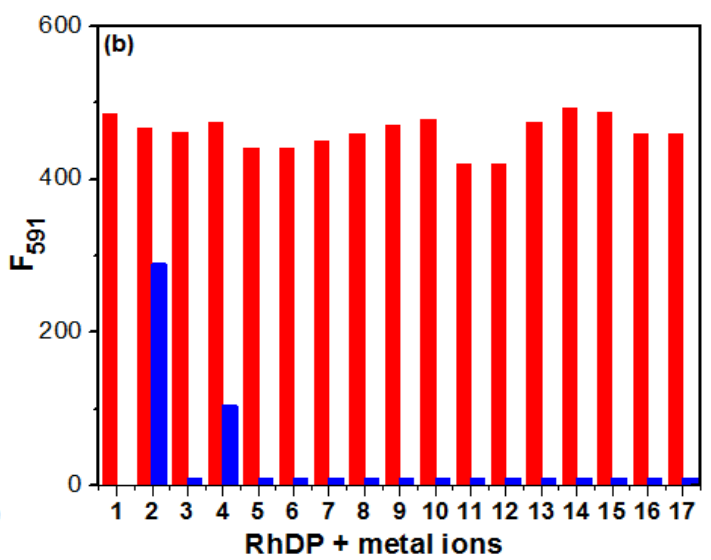

Figure 4: (a) Variation of absorption values $(557 \mathrm{~nm})$ of $\operatorname{RhDP}(20 \mu \mathrm{M})$ and $\operatorname{RhDP}+\mathrm{Cd}^{2+}(20 \mu \mathrm{M})$ at various $\mathrm{pH}$ values. (b) Fluorescence intensities of RhDP with various metal ions (blue bars) and the subsequent addition of $\mathrm{Cd}^{2+}$ (red bars): $1, \mathrm{Cd}^{2+} ; 2, \mathrm{Cu}^{2+} ; 3, \mathrm{Zn}^{2+} ; 4, \mathrm{Co}^{2+} ; 5, \mathrm{Cr}^{3+} ; 6, \mathrm{Ni}^{2+} ; 7, \mathrm{Hg}^{2+} ; 8, \mathrm{Mn}^{2+}$; $9, \mathrm{~Pb}^{2+} ; 10, \mathrm{Ag}^{+} ; 11, \mathrm{Cu}^{+} ; 12, \mathrm{Fe}^{3+} ; 13, \mathrm{~K}^{+} ; 14, \mathrm{Na}^{+} ; 15, \mathrm{Mg}^{2+} ; 16, \mathrm{Ca}^{2+} ; 17, \mathrm{Fe}^{2+}$.

In order to confirm the binding stoichiometry between RhDP and $\mathrm{Cd}^{2+}$, Job's plot and absorption/ fluorescent titration spectra were carried out. As shown in Figure 5a (Job's plot), $\mathrm{RhDP} / \mathrm{Cd}^{2+}$ molar fractions represented a maximum absorption peak (at $557 \mathrm{~nm}$ ) when it was close to 0.5, which indicated that the binding between RhDP and $\mathrm{Cd}^{2+}$ was in 1:1 stoichiometry. Typical UV-Vis titration and fluorescent intensity spectra for RhDP with $\mathrm{Cd}^{2+}$ were shown in Figure $3 a$ (see inset in the

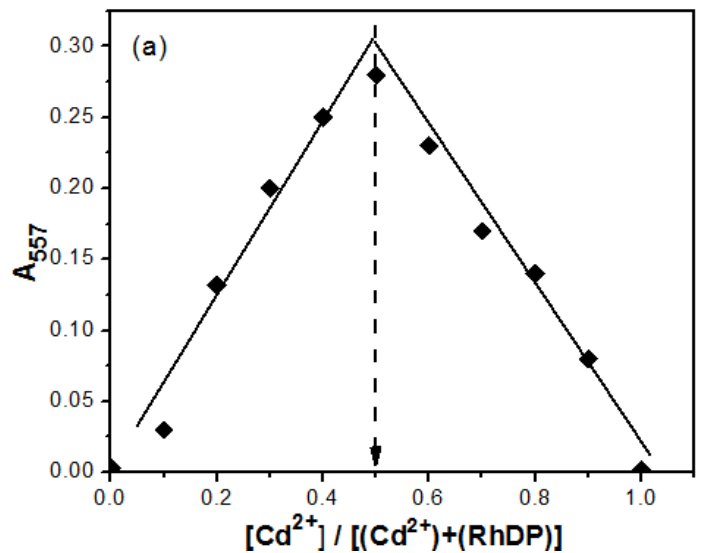

Figure) and Figure 5b. As seen in the Figures, the $\mathrm{RhDP} / \mathrm{Cd}^{2+}$ molar ratio (for both absorption and fluorescent results) reached a plateau when the concentration of $\mathrm{Cd}^{2+}$ and an equivalent amount of RhDP was close to $1: 1$, suggesting the formation of a 1:1 RhDP-Cd ${ }^{2+}$ complex. The binding constant between $\mathrm{Cd}^{2+}$ and RhDP was determined by a previously reported method (42) with absorption values at $557 \mathrm{~nm}$ and was determined to be 2.70 $\times 10^{7} \mathrm{M}^{-1}$.

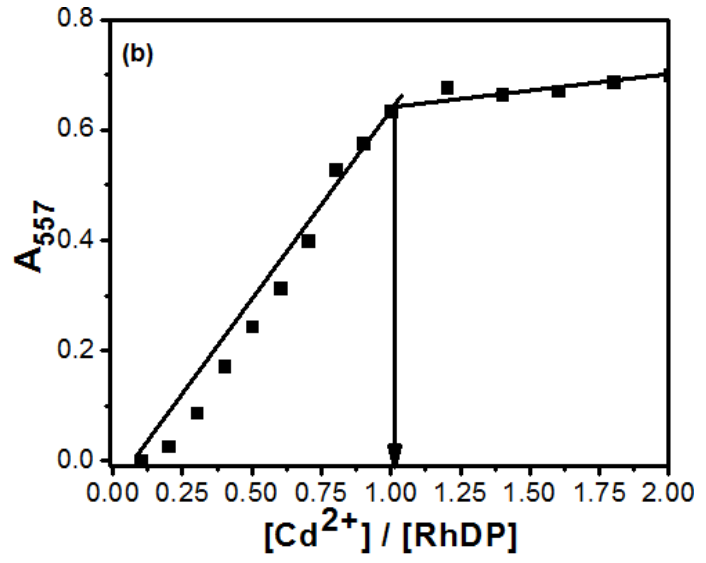

Figure 5: (a) Job's plot (b) Titration of $20 \mathrm{~mm}$ RhDP with increasing concentrations of $\mathrm{CdCl}_{2}(0,2,4,6$, $8,10,12,14,16,18,20,25,30,35,40 \mu \mathrm{M}$ respectively) in ACN/HEPES buffer (10 mM, pH: 7.05.

Furthermore, the reversibility of the binding between RhDP and $\mathrm{Cd}^{2+}$ was examined. The complex solution of the sensor and $\mathrm{Cd}^{2+}$ was treated with a solution of EDTA (5.0 equivalent).
As seen in Figure 6, the fluorescence signals of RhDP-Cd ${ }^{2+}$ disappeared, which indicated that the binding RhDP and $\mathrm{Cd}^{2+}$ is reversible. 


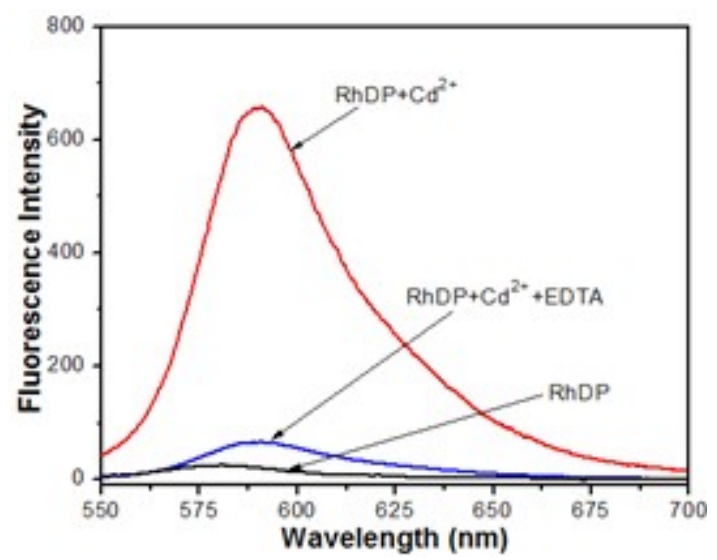

Figure 6: Fluorescence emissions showing reversibility of RhDP $(20 \mu \mathrm{M})$ to $\mathrm{Cd}^{2+}$ ions by EDTA.

From the above results RhDP coordinates with $\mathrm{Cd}^{2+}$ reversible binding mode of RhDP-Cd ${ }^{2+}$ is presented in a $1: 1$ binding mode. The proposed $1: 1$ in Scheme 2.

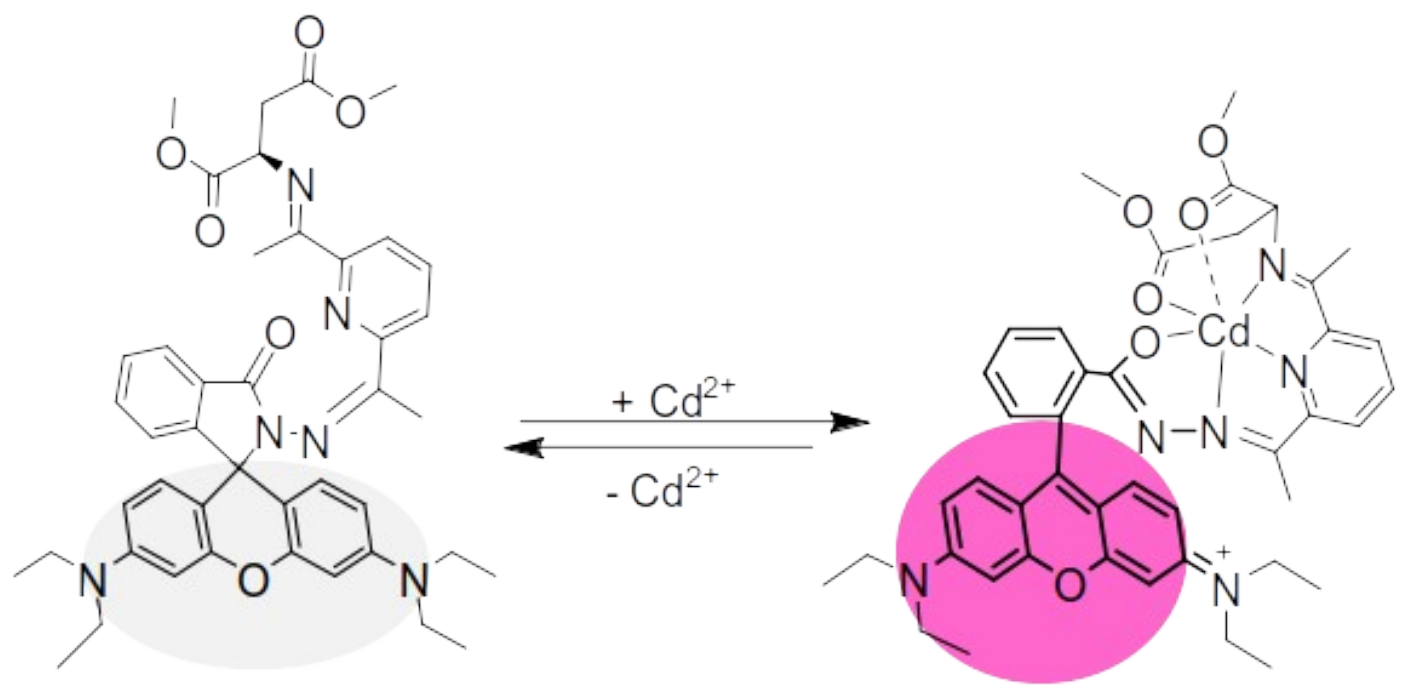

Scheme 2: Proposed reversible binding mechanism between RhDP and $\mathrm{Cd}^{2+}$. The structure on the left is ring-closed form and is very weakly fluorescent. The structure on the right is ring-opened form and is strongly fluorescent.

Moreover, the linear concentration range and the fluorescent detection limit of RhDP were obtained. The range of fluorescent intensity (at $591 \mathrm{~nm}$ ) was linearly dependent on the concentration of $\mathrm{Cd}^{2+}$ in the range from 0 to $20 \mu \mathrm{M}\left(R^{2}=0.998\right)$. The fluorescent detection limit was calculated to be $0.218 \mu \mathrm{M}$ based on $3 \sigma / \mathrm{k}$ (Figure 7 ). 


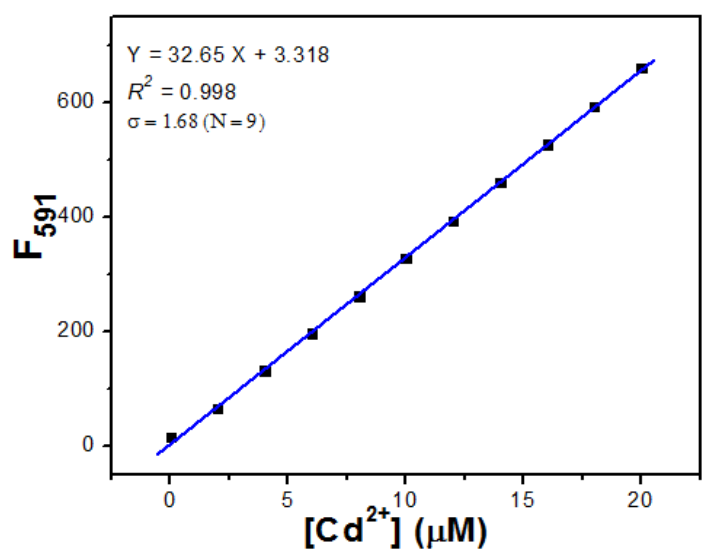

Figure 7: Linear relationship between fluorescent intensity and $\mathrm{Cd}^{2+}$ concentration (0-20 $\left.\mu \mathrm{M}\right)$ Limit of detection (LOD) of RhDP towards $\mathrm{Cd}^{+}$by fluorescent method.

In summary, a new turn-on rhodamine based fluorescent sensor RhDP was designed and synthesized for selective detection of $\mathrm{Cd}^{2+}$ ions in aqueous solutions. The sensor showed an excellently selective fluorescence enhancement for $\mathrm{Cd}^{2+}$ over other metal ions tested with a colour change and reversible response. The complex stoichiometry between RhDP and $\mathrm{Cd}^{2+}$ was found to be $1: 1$ and the binding constant was calculated as $2.70 \times 10^{7} \mathrm{M}^{-1}(\log K=7.43)$ in ACN/HEPES buffer $(10 \mathrm{mM}, \mathrm{pH}: 7.05, \mathrm{v} / \mathrm{v} 1: 1)$. The fluorescent detection limit of RhDP for $\mathrm{Cd}^{2+}$ was found to be $0.218 \mu \mathrm{M}$, which gave a marked sensitivity towards $\mathrm{Cd}^{2+}$.

\section{REFERENCES}

1. Wang C, Fang Y, Peng S, Ma D, Zhao J. Synthesis of novel chelating agents and their effect on cadmium decorporation. Chemical Research in Toxicology. 1999;12(4):331-4.

2. Williams C, David D. The effect of superphosphate on the cadmium content of soils and plants. Soil Research. 1973;11(1):43-56.

3. Salviano Mendes AM, Duda GP, Araujo do Nascimento CW, Silva MO. Bioavailability of cadmium and lead in a soil amended with phosphorus fertilizers. Scientia Agricola. $2006 ; 63(4): 328-32$.

4. Prozialeck WC, Edwards JR, Woods JM. The vascular endothelium as a target of cadmium toxicity. Life Sciences. 2006;79(16):1493-506.

5. Varriale A, Staiano M, Rossi M, D'Auria S. High-affinity binding of cadmium ions by mouse metallothionein prompting the design of a reversed-displacement protein-based fluorescence biosensor for cadmium detection. Analytical Chemistry. $2007 ; 79(15): 5760-2$.
6. Can IAfRo. IARC monographs on the evaluation of the carcinogenic risks to humans: beryllium, cadmium, mercury, and exposures in the glass manufacturing industry: World Health Organization; 1993.

7. McFarland C, Bendell-Young L, Guglielmo C, Williams T. Kidney, liver and bone cadmium content in the Western Sandpiper in relation to migration. Journal of Environmental Monitoring. 2002;4(5):791-5.

8. Goyer RA, Liu J, Waalkes MP. Cadmium and cancer of prostate and testis. Biometals. 2004;17(5):555-8.

9. Satarug $S$, Baker JR, Urbenjapol $S$, Haswell-Elkins M, Reilly PE, Williams DJ, et al. A global perspective on cadmium pollution and toxicity in non-occupationally exposed population. Toxicology Letters. 2003;137(1-2):65-83.

10. Ye Q-y, Li $Y$, Jiang $Y$, Yan $X-p$. Determination of trace cadmium in rice by flow injection on-line filterless precipitation- dissolution preconcentration coupled with flame atomic absorption spectrometry. Journal of Agricultural Food Chemistry. 2003;51(8):2111-4.

11. Pyle SM, Nocerino JM, Deming SN, Palasota JA, Palasota JM, Miller EL, et al. Comparison of AAS, ICP-AES, PSA, and XRF in determining lead and cadmium in soil. Environmental Science Technology. 1995;30(1):204-13.

12. Dolan SP, Nortrup DA, Bolger PM, Capar SG. Analysis of dietary supplements for arsenic, cadmium, mercury, and lead using inductively coupled plasma mass spectrometry. Journal of Agricultural Food Chemistry. 2003;51(5):1307-12.

13. Bakker E, Pretsch E. Potentiometric sensors for trace-level analysis. Trends in Analytical Chemistry. 2005;24(3):199-207. 
14. Prabhakaran $D$, Yuehong $M$, Nanjo $H$, Matsunaga $H$. Naked-eye cadmium sensor: using chromoionophore arrays of Langmuir-Blodgett molecular assemblies. Analytical Chemistry. 2007;79(11):4056-65.

15. Zhu $\mathrm{Y}-\mathrm{F}$, Wang $\mathrm{Y}-\mathrm{S}$, Zhou $\mathrm{B}, \mathrm{Yu} \mathrm{J}-\mathrm{H}$, Peng $L-L$, Huang $Y-Q$, et al. A multifunctional fluorescent aptamer probe for highly sensitive and selective detection of cadmium(II). Analytical Bioanalytical Chemistry. 2017;409(21):4951-8.

16. Choi M, Kim M, Lee KD, Han K-N, Yoon I-A, Chung $\mathrm{H}-\mathrm{J}$, et al. A new reverse PET chemosensor and its chelatoselective aromatic cadmiation. Organic Letters. 2001;3(22):3455-7.

17. Zhang $Y$, Zhang Z, Yin D, Li J, Xie R, Yang W. Turn-on fluorescent InP nanoprobe for detection of cadmium ions with high selectivity and sensitivity. ACS Applied Materials Interfaces. 2013;5(19): 9709-13.

18. Shim S, Tae J. Rhodamine Cyclen-based fluorescent chemosensor for the detection of $\mathrm{Cd}^{2+}$. Bulletin of the Korean Chemical Society. 2011;32:2928-32.

19. Kim HN, Ren WX, Kim JS, Yoon J. Fluorescent and colorimetric sensors for detection of lead, cadmium, and mercury ions. Chemical Society Reviews. 2012;41(8):3210-44.

20. Nolan EM, Ryu JW, Jaworski J, Feazell RP, Sheng $M$, Lippard SJ. Zinspy sensors with enhanced dynamic range for imaging neuronal cell zinc uptake and mobilization. Journal of the American Chemical Society. 2006;128(48):1551728.

21. Komatsu K, Kikuchi K, Kojima H, Urano $\mathrm{Y}$, Nagano T. Selective zinc sensor molecules with various affinities for $\mathrm{Zn}^{2+}$, revealing dynamics and regional distribution of synaptically released $\mathrm{Zn}^{2+}$ in hippocampal slices. Journal of the American Chemical Society. 2005;127(29):10197-204.

22. Gunnlaugsson T, Lee TC, Parkesh R. Highly selective fluorescent chemosensors for cadmium in water. Tetrahedron. 2004;60(49):11239-49.

23. Xue L, Li G, Liu Q, Wang H, Liu C, Ding X, et al. Ratiometric fluorescent sensor based on inhibition of resonance for detection of cadmium in aqueous solution and living cells. Inorganic Chemistry. 2011;50(8):3680-90.

24. Xue L, Liu $C$, Jiang $H$. Highly sensitive and selective fluorescent sensor for distinguishing cadmium from zinc ions in aqueous media. Organic Letters. $2009 ; 11(7): 1655-8$.

25. Chen $X$, Pradhan $T$, Wang $F$, Kim JS, Yoon J. Fluorescent chemosensors based on spiroringopening of xanthenes and related derivatives. Chemical Reviews. 2011;112(3):1910-56

26. Dujols V, Ford F, Czarnik AW. A longwavelength fluorescent chemodosimeter selective for $\mathrm{Cu}(\mathrm{II})$ ion in water. Journal of the American Chemical Society. 1997;119(31):7386-7.

27. Shiraishi $Y$, Sumiya S, Kohno $Y$, Hirai T. A rhodamine- cyclen conjugate as a highly sensitive and selective fluorescent chemosensor for $\mathrm{Hg}$ (II). The Journal of Organic Chemistry. 2008;73(21):8571-4.

28. Bhalla V, Sharma N, Kumar N, Kumar M. Rhodamine based fluorescence turn-on chemosensor for nanomolar detection of $\mathrm{Fe}^{3+}$ ions. Sensors Actuators B: Chemical. 2013;178:228-32.

29. Weerasinghe AJ, Schmiesing C, Sinn E. Highly sensitive and selective reversible sensor for the detection of $\mathrm{Cr}^{3+}$. Tetrahedron Letters. 2009;50(46):6407-10.

30. Jiao Y, Zhou L, He H, Yin J, Gao Q, Wei J, et al. A novel rhodamine B-based "offon"fluorescent sensor for selective recognition of copper(II) ions. Talanta. 2018;184:143-8.

31. Adak AK, Purkait R, Manna SK, Ghosh BC, Pathak $S$, Sinha $C$. Fluorescence sensing and intracellular imaging of $\mathrm{Pd}^{2+}$ ions by a novel coumarinyl-rhodamine Schiff base. New Journal of Chemistry. 2019;43(9):3899-906.

32. Goswami S, Aich K, Das S, Das AK, Manna A, Halder S. A highly selective and sensitive probe for colorimetric and fluorogenic detection of $\mathrm{Cd}^{2+}$ in aqueous media. Analyst. 2013;138(6):1903-7.

33. Aich K, Goswami S, Das S, Mukhopadhyay $\mathrm{CD}$, Quah CK, Fun H-K. Cd2+ triggered the FRET "ON": a new molecular switch for the ratiometric detection of $\mathrm{Cd}^{2+}$ with live-cell imaging and bound $X$-ray structure. Inorganic Chemistry. 2015;54(15):7309-15.

34. Maniyazagan $M$, Mariadasse $R$, Jeyakanthan J, Lokanath N, Naveen S, Premkumar $\mathrm{K}$, et al. Rhodamine based "turn-on" molecular switch FRET-sensor for cadmium and sulfide ions and live cell imaging study. Sensors Actuators B: Chemical. 2017;238:565-77.

35. Sakthivel P, Sekar K, Sivaraman G, Singaravadivel $S$. Rhodamine diaminomaleonitrile 
conjugate as a novel colorimetric fluorescent sensor for recognition of $\mathrm{Cd}^{2+}$ ion. Journal of Fluorescence. 2017;27(3):1109-15.

36. Soibinet $M$, Souchon V, Leray I, Valeur BJ. Rhod-5N as a fluorescent molecular sensor of cadmium(II) ion. Journal of Fluorescence. $2008 ; 18(6): 1077$.

37. Aydin Z, Wei Y, Guo M. An "off-on" optical sensor for mercury ion detection in aqueous solution and living cells. Inorganic Chemistry Communications. 2014;50:84-7.

38. Taylor D, Demas J. Light intensity measurements I: Large area bolometers with microwatt sensitivities and absolute calibration of the Rhodamine B quantum counter. Analytical Chemistry. 1979;51(6):712-7.
39. Kim HN, Lee $\mathrm{MH}, \mathrm{Kim} \mathrm{HJ}$, Kim JS, Yoon J. A new trend in rhodamine-based chemosensors: application of spirolactam ring-opening to sensing ions. Chemical Society Reviews. 2008;37(8):146572.

40. Wei Y, Aydin Z, Zhang Y, Liu Z, Guo M. A turn-on fluorescent sensor for imaging labile $\mathrm{fe}^{3+}$ in live neuronal cells at subcellular resolution. ChemBioChem. 2012;13(11):1569-73.

41. Aydin Z, Wei Y, Guo M. A highly selective rhodamine based turn-on optical sensor for $\mathrm{Fe}^{3+}$. Inorganic Chemistry Communications. 2012;20:93-6.

42. Guo M, Perez C, Wei Y, Rapoza E, Su G, Bou-Abdallah $F$, et al. Iron-binding properties of plant phenolics and cranberry's bio-effects. Dalton Transactions. 2007(43):4951-61. 
Aydin Z. JOTCSA. 2020; 7(1): 277-286.

RESEARCH ARTICLE 